\title{
Determinants of blood-lead levels in children in Callao and Lima metropolitan area
}

Rocío Espinoza, MD, (1) Mauricio Hernández-Avila, MD, MPh, $\mathrm{ScD}$, (2) Juan N arciso, Eng, ${ }^{(1)}$ C armen C astañaga, MD, (1)

Shirley Moscoso, Biól, ${ }^{(1)}$ Georgina 0 rtiz, MD, ${ }^{(1)}$ Luz C arbajal, MD, ${ }^{(3)}$ Steve W egner, MD, ${ }^{(4)}$ Gary N oonan, Eng.(5)

Espinoza R, Hernández-Avila M, Narciso J, Castañaga C, Moscoso S, Ortiz G, Carbajal L, Wegner S, Noonan G. Determinants of blood-lead levels in children in Callao and Lima metropolitan area. Salud Publica Mex 2003;45 supl 2:S209-S219. The English version of this paper is available too at: http://www.insp.mx/salud/index.html

\begin{abstract}
A bstract
Objectives To determine blood lead levels in urban populations of children $(n=2510)$ and women $(n=874)$ in the early postpartum in certain districts of Lima and C allao, and to correlate those levels with particular exposures. Material and Methods. Between July 1998 and January 1999 cross sectional study was conducted. The study population was selected using three sampling strategies in the government operated school system and from public pediatric and maternity hospitals at Lima and Callao, Peru. Study personnel were trained to collect finger stick blood samples with a pro to col that minimizes external lead contamination. Lead determinations in blood and environmental samples were performed at the study site using portable anodic striping voltamenters. To determine the simultaneous effects of different predictors on blood lead levels, multivariate regression models were used to estimate adjusted mean differences. Results The mean blood lead level in the children studied was $9.9 \mu \mathrm{g} / \mathrm{dl}$ ranging from I $\mu \mathrm{g} / \mathrm{dl}$ to $64 \mu \mathrm{g} / \mathrm{dl}$ with $29 \%$ of the children displaying values greater than $10 \mu \mathrm{g} / \mathrm{dl}$ and $9.4 \%$ at levels greater than $20 \mu \mathrm{g} / \mathrm{dl}$.A mong the women, the mean was $3.5 \mu \mathrm{g} / \mathrm{dl}(S D=2.4 \mu \mathrm{g} / \mathrm{dl})$, and $2.4 \%(\mathrm{n}=21)$
\end{abstract}

\author{
Espinoza R, Hernández-Avila M, Narciso J, \\ Castañaga C, Moscoso S, Ortiz G, \\ Carbajal L, Wegner S, Noonan G. \\ Determinación de los niveles de plomo en sangre de niños \\ de El Callao y del área metropolitana de Lima. \\ Salud Publica Mex 2003;45 supl 2:S209-5219. \\ El texto completo en inglés de este artículo también \\ está disponible en: http://www.insp. mx/salud/index.html
}

\section{Resumen}

Objetivos D eterminar los niveles de plomo en sangre en una muestra compuesta por niños y mujeres en el pospar to temprano, residentes en Lima y El Callao. Investigar los determinantes de estos niveles y algunas fuentes de exposición. Material y métodos Entre julio de 1998 y enero de 1999 se llevó a cabo una encuesta en el área metropolitana de Lima y en El Callao, Perú. La población de estudio fue identificada mediante tres estrategias de muestreo y con la cual se seleccionaron escuelas públicas y hospitales pediátricos y gineco-obstétricos. El personal que participó en el estudio recibió entrenamiento para la técnica de punción digital y puso especial énfasis en controlar la contaminación externa con plomo. Las determinaciones del metal en sangre y muestras ambientales se llevaron a cabo utilizando voltametría anódica. Para determinar los efectos simultáneos de diferentes predictores sobre los niveles de plomo en sangre se usaron modelos de regresión multivariada para estimar diferencias de media y ajustadas. Resultados Los niveles promedio de plomo en sangre fueron de $9.9 \mu \mathrm{g} / \mathrm{dl}$ de una variación entre 0 y $64 \mu \mathrm{g} / \mathrm{dl}$. El 29 y $9.4 \%$ de los niños presentaron valores por encima de 10

Supported by funding from the United States A gency for International D evelopment (USAID), Peru Mission, Environmental Strategic 0 bjective Team, Lima, Peru.

(1) Dirección General de Salud A mbiental. Dirección de Salud 0 cupacional. Lima, Perú.

(2) Centro de Investigación en Salud Poblacional, Instituto N acional de Salud Pública, Cuernavaca, Morelos, México.

(3) Departamento de Estadística, Universidad Peruana Cayetano Heredia, Lima, Perú.

(4) N orth Carolina Access Care, N orth Carolina, US

(5) N ational Centers for Enviromental Health, Center for Disease Control and Prevention.

Received on: May 15,2003 - Acepted on: September 22, 2003

Address reprint requests to: Dr. Mauricio Hemández Avila, Instituto N acional de Salud Pública,Avenida Universidad 655, colonia Santa María A huacatitlán 62508, Cuernavaca, Morelos, México. 
displayed levels greater than $10 \mu \mathrm{g} / \mathrm{dl}$. Important differences were observed between the sample locations, and the highest levels were documented in the port region near $C$ allao. The mean level of blood lead in this group was $25.6 \mu \mathrm{g} / \mathrm{dl}$ $(S D=4.6 \mu \mathrm{g} / \mathrm{d} \mathrm{l})$, while among the rest of the sample it was $7.1 \mu \mathrm{g} / \mathrm{dl}(\mathrm{SD}=5.1 \mu \mathrm{g} / \mathrm{dl})$. The presence of a mineral storage area signified a difference in exposure in excess of $13 \mu \mathrm{g} / \mathrm{dl}$ for children living near the port area in contrast to the other children who were not as close to such fixed sources of lead exposure. For the participants in Lima, the risk of showing levels above $10 \mu \mathrm{g} / \mathrm{dl}$ was associated with exposure to high vehicular traffic. Conclusions. In metropolitan Lima, we conclude that the mean blood lead levels of the populations studied were not alarming and that a positive health impact can be made by a reduction of lead in gasoline.W ith regard to the port area, the study demonstrates that the presence of mineral storage areas pose a detrimental risk factor for the health of the children living in this area. The English version of this paper is available too at: http:// www.insp.mx/salud/index.html

Key words: blood lead; child; environment; Peru $\mu \mathrm{g} / \mathrm{dl}$ y $20 \mu \mathrm{g} / \mathrm{dl}$,respectivamente. Para las mujeres el promedio de plomo en sangre fue de $3.5 \mu \mathrm{g} / \mathrm{dl}(\mathrm{DE}=2.4)$ y $2.4 \%$ $(n=2 l)$ presentaron niveles superiores a $10 \mu \mathrm{g} / \mathrm{dl}$. Se observaron diferencias importantes en relación con el sitio de residencia; los niveles más altos se documentaron en la zona de El Callao. Para este grupo la media de plomo en sangre fue de $25.6 \mu \mathrm{g} / \mathrm{dl}(\mathrm{DE}=4.6)$ mientras que para el resto de la muestra el promedio de plomo en sangre fue de $7.1 \mu \mathrm{g} / \mathrm{dl}$ $(D E=5$. .). En esta zona se detectó un área de almacenamiento de minerales como una fuente importante de exposición. Los niños que viven cerca de esta área tenían en promedio un exceso de $13 \mu \mathrm{g} / \mathrm{dl}$ en sangre. Para los participantes de la zona de Lima el riesgo de presentar niveles por encima de $10 \mu \mathrm{g} / \mathrm{dl}$ se asoció con la exposición a tráfico vehicular. Conclusiones. Para Lima Metro po litana se puede concluir que los niveles de plomo en sangre no representan un problema urgente, sin embargo, el reducir el plomo de la gasolina se acompaña de un beneficio importante. En contraste, para el área cercana al puerto de El C allao, nuestro estudio demuestra la presencia de sitios de almacenamiento de minerales que representan un riesgo importante para la salud de los niños que viven en esta zona. El texto completo en inglés de este artículo también está disponible en: http:// www.insp.mx/salud/index.html

Palabras clave: plomo en sangre; niño; ambiente; Perú
A ir pollution is an emerging public health problem in Peru that affects more than eight million individuals living in different urban areas of the country. In Peru, significant amounts of lead can still be found in gasoline ( 0.75 grams per liter), but the public health impact of this exposure has not been documented. The growing evidence for a direct link between low-level lead exposure and deficits in the neurobehavioral-cognitive performance evidenced in childhood through adolescence has led to a worldwide initiative to reduce the lead content of gasoline. ${ }^{1}$ Following this initiative the Peruvian government has committed itself to the reduction and elimination of the use of lead in gasoline. In this paper we report the results of a large cross-sectional study that was designed to determine the current levels of exposure to lead, in order to define potential sources of lead and to provide the baseline blood lead concentrations necessary to monitor changes associated with the phasing -out of leaded gasoline.

\section{Material and Methods}

The study was carried out between July 1998 and January 1999, and included populations from Metropolitan Lima and Callao, the port area nearby (see Figure
I). The sample studied consisted of 2510 children between 6 months and 11 years of age and 874 women in the early postpartum. The study population was selected using three sampling strategies: 1) Children aged 3 to 11 years were recruited through the government operated school system. For this purpose 15 schools were selected at random reflecting different districts in Lima and Callao with different vehicular traffic intensity and of medium to low socio-economic level $(n=1$ 539). 2) Children from 1 to 35 months of age $(n=971)$ were recruited at random from five public hospitals and one primary health center in Callao among children who attended for a healthy child visit during the study period. 3) Women in the immediate postpartum were selected at random using a systematic sampling of women delivering in five Government Operated Maternity Hospitals. This group was selected to estimate blood lead levels at birth, because the blood lead levels of women have been highly correlated with the blood lead levels of their developing fetuses and newborn infants. ${ }^{2-4}$ All participants and parents of the children were recruited at schools or pediatric service locations, provided written consent and answered a short questionnaire regarding potential sources of lead exposure that included: habits of the children (chewing and sucking pencils, eating soil, biting and eating 


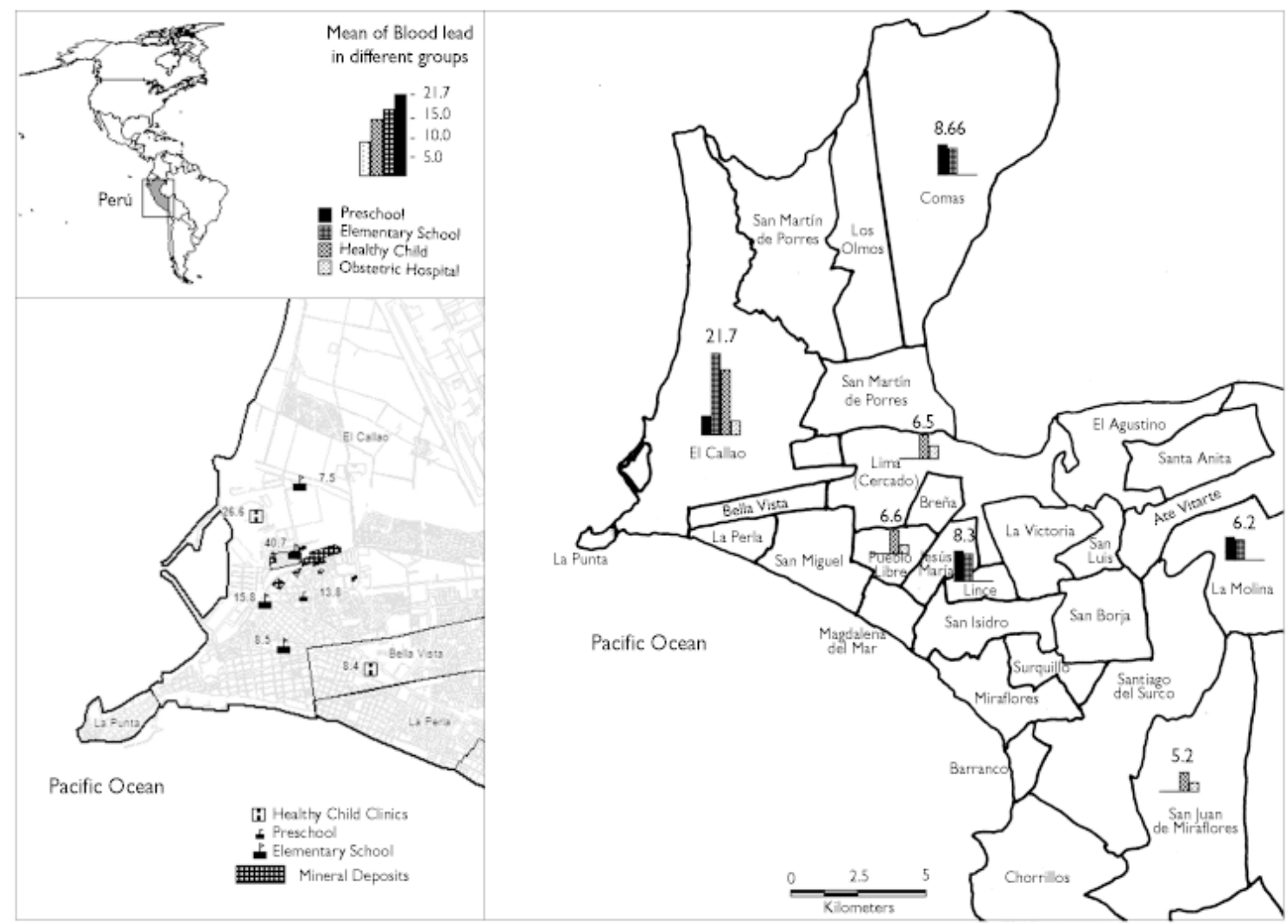

Figure 1. Mean of blood lead levels in children and women in Lima and Callao, Peru, 1998-1999

fingernails), personal hygiene (number of hand washings), environmental exposure (time in outdoor environments and type of transportation used to go to school), place of residence in relation to vehicular traffic intensity and other potential sources of exposure to lead, types of water utilized, habits in the preparation of food for the children, and the occupation of parents, husbands, or other household members.

\section{Blood samples}

Study personnel were trained in the processes of hand washing and the collection of finger stick blood samples according to a protocol that minimized the potential for lead contamination. Hand washing of the participants was performed and supervised by study personnel. The fingers were meticulously washed, and after drying them participants were asked to place their hands in a prayer-like manner to avoid contamination. A small sample of blood, $50 \mu$, was obtained by puncturing the ring finger. The blood sample was placed in capillary tubes with heparin. Portable anodic voltam- etry was used to determine blood lead levels. The sensitivity of the instrument used is adequate for blood lead levels between 1.4 and $65 \mu \mathrm{g} / \mathrm{dl}$, it requires neither manual calibration nor refrigeration, and provides blood lead levels in a few minutes. ${ }^{5-7}$ All participants (or their parents in the case of the children) received information and counseling regarding their blood lead levels and, if necesary, written information indicating how to reduce their exposure to lead. When the blood lead level was higher than $20 \mu \mathrm{g} / \mathrm{dl}$, study personnel collected an additional venous sample with heparin $(3$ to $5 \mathrm{ml}$ ) and these blood lead levels were analyzed by atomic absorption. ${ }^{8}$ Th quality control to analyze blood lead levels by atomic absorption was done in collaboration with the Center for Disease Control $^{9}$ whereby control samples with known values of lead were sent to the laboratory in Lima.

\section{Environmental samples}

In the initial phase of the study it became apparent that children living in a poor neighborhood of Callao had 
abnormally high blood lead levels (mean $25.7 \mu \mathrm{g} / \mathrm{dl}$ ). In order to investigate potential sources of exposure for this population, study personnel visited the area and identified large open areas where considerable quantities of mineral concentrate was stored. The storage sites covered an estimated area of $147000 \mathrm{~m}^{2}$ in the vicinity of the port in Callao. These facilities provide temporary storage for metals, metal concentrates and other mining products before they are exported by ship. To assess the potential contribution of these areas as sources of lead exposure, we collected soil samples from the interior of the source point and at different distances $(300 \mathrm{~m}, 600 \mathrm{~m}, 900 \mathrm{~m}$ and $1200 \mathrm{~m})$, following an enlarging circumference pattern around the point source. The samples of soil were obtained from surface soil, not exceeding a depth of $2 \mathrm{~cm}$ according to the recommendations of the $\mathrm{CDC}^{10-12} \mathrm{~A}$ limited number of water samples were also collected. Lead determination of the environmental samples was performed using ultrasonic extraction. Weighed quantities of paint and soil, as well as towelettes that were used to sample for dust, were placed into $50 \mathrm{ml}$ polypropylene centrifuge tubes. Instrument-grade nitric acid $17.5 \%$ (25\% by Environmental Protection Agency (EPA) method) was introduced into each centrifuge tube with a mechanical pipet $(15 \mathrm{ml}$ for dust samples and $5 \mathrm{ml}$ for soil samples) and the tubes were capped. Samples were then placed in an ultrasonic bath, subjected to ultrasonic energy for 30 minutes, cooled to room temperature, and allowed to settle before final dilution to $50 \mathrm{ml}$ with distilled water. We used a battery powered 400-g portable anodic stripping voltameter (ASV) with disposable electrodes for analyses of soil and dust. Five milliliter aliquots of extracted and diluted sample were placed in $5 \mathrm{ml}$ polypropylene sample vials. An electrolyte pill was introduced to each aliquot and crushed with a plastic stirring rod, the aliquot was shaken to ensure complete dissolution of the electrolyte. ASV determination of lead in water was similar except that a different electrolyte pill was used. ${ }^{10,11}$

\section{Statistical analysis}

Univariate and bivariate statistics, tabulations, and distribution plots were examined for all variables. Place of residency (Lima versus Callao) was identified as an important determinant of blood lead levels and we therefore performed the analyses for the total sample as well as for Lima and Callao as separate strata.

To determine the simultaneous effects of different predictors on blood lead levels, multivariate regression models were used to estimate adjusted mean differ- ences. To assess the impact of different variables in terms of the risk of having high blood lead levels, blood lead level was modeled using logistic regression where the dependent variable was categorized as 1 for subjects with values greater than $10 \mu \mathrm{g} / \mathrm{dl}$ and 0 for those with values less than or equal to $10 \mu \mathrm{g} / \mathrm{dl}$. In this phase of the analysis we estimated odds ratios to assess the association between blood lead and other variables using multivariate logistic regression.

\section{Results}

\section{Child Population}

During the study period 2510 children with a mean age of 4.5 years (range 6 months to 11 years) were recruited (Figure 1). The mean blood lead level for the study population was $9.9 \mu \mathrm{g} / \mathrm{dl}$ (range $1 \mu \mathrm{g} / \mathrm{dl}$ to 64 $\mu \mathrm{g} / \mathrm{dl})$. Twenty-nine percent of the children had blood lead levels higher than $10 \mu \mathrm{g} / \mathrm{dl}$ and $9.4 \%$ had blood lead levels over $20 \mu \mathrm{g} / \mathrm{dl}$.

Blood lead levels varied significantly by place of residency. The observed blood lead levels were 7.1 $\mu \mathrm{g} / \mathrm{dl}(\mathrm{SD}=5.1)$ and $9.6 \mu \mathrm{g} / \mathrm{dl}(\mathrm{SD}=6.2)$ for Lima and Callao, respectively. Variation in blood lead levels in Callao became even more apparent when we stratified the population according to the selected schools (Table I). Two schools and a primary health center in Puerto Nuevo, a small poor neighborhood located in Callao, were situated close to a large area used for the temporary storage of mineral concentrates. The mean of blood lead levels in these schools and the health center were $40.7 \mu \mathrm{g} / \mathrm{dl}, 15.8 \mu \mathrm{g} / \mathrm{dl}$ and $26.6 \mu \mathrm{g} / \mathrm{dl}$, respectively.

The analysis of the results of the environmental soil samples (46 samples) demonstrated an inverse correlation between lead in soil and distance from the mineral storage areas. When the distance was $300 \mathrm{~m}$ the lead levels were between 900 and $2859 \mathrm{~g} / \mathrm{g}$ as compared to a distance of between $901 \mathrm{~m}$ to $1200 \mathrm{~m}$ where the lead level decreased to $214 \mathrm{~g} / \mathrm{g}$. (Figure 2).

The concentrations of lead in water were all below $7 \mathrm{ppb}$, which is the threshold value recommended by the World Health Organization (WHO).

\section{Determinants of blood- lead levels}

The habit of eating soil or sucking or biting pencils, crayons or modeling clay were associated with statistically significant higher blood lead levels. Twelve percent of the interviewed parents reported positively that their children had the habit of eating soil; in this group we observed a significant excess of $2.3 \mu \mathrm{g} / \mathrm{dl}$ in the mean blood lead level. Equally, the participants whose 
Table I

Mean blood lead leVels, Distribution OF FREQUENCY AND PERCENTAGE OF PARTICIPANTS ACCORDING TO DISTRICT AND SCHOOL.1998-1999

\begin{tabular}{|c|c|c|c|c|c|}
\hline \multirow[b]{2}{*}{ District } & \multicolumn{3}{|c|}{ Children } & \multirow{2}{*}{$\begin{array}{l}\text { M ean } \\
\mu \mathrm{g} / \mathrm{dl}\end{array}$} & \multirow{2}{*}{$\begin{array}{c}\text { S.D. } \\
\mu \mathrm{g} / \mathrm{d}\end{array}$} \\
\hline & Recruitment Centers & Number & $\%$ & & \\
\hline \multirow[t]{5}{*}{ Comas } & Elementary school & 119 & 4.74 & 6.64 & 2.66 \\
\hline & Elementary school & 141 & 5.62 & 7.43 & 2.97 \\
\hline & Pre-school & 22 & 0.88 & 6.78 & 2.18 \\
\hline & Pre-school & 60 & 2.39 & 10.54 & 7.43 \\
\hline & Elementary school & 75 & 2.99 & 7.54 & 4.26 \\
\hline \multirow[t]{4}{*}{ Callao } & Elementary school & 166 & 6.61 & 8.58 & 4.44 \\
\hline & *Elementary school & 68 & 2.71 & 40.73 & 12.96 \\
\hline & *Elementary school & 119 & 4.74 & 15.88 & 9.81 \\
\hline & *Pre-school & 130 & 5.18 & 13.87 & 8.01 \\
\hline \multirow[t]{2}{*}{ Callao } & Healthy child clinic & 213 & 8.49 & 8.44 & 5.56 \\
\hline & *H ealthy child clinic & 127 & 5.05 & 26.66 & 11.96 \\
\hline \multirow[t]{3}{*}{ La Molina } & a Elementary school & 44 & 1.75 & 5.54 & 2.89 \\
\hline & Elementary school & 72 & 2.87 & 5.80 & 2.89 \\
\hline & Pre-school & 103 & 4.1 & 6.24 & 2.56 \\
\hline \multirow[t]{3}{*}{ Lince } & Pre-school & 198 & 7.89 & 8.31 & 4.06 \\
\hline & Elementary school & 84 & 3.35 & 5.91 & 1.82 \\
\hline & Elementary school & 138 & 5.5 & 9.39 & 3.89 \\
\hline \multirow[t]{2}{*}{ Lima } & Healthy child clinic & 185 & 7.37 & 6.72 & 4.27 \\
\hline & Healthy child clinic & 200 & 7.97 & 6.37 & 4.14 \\
\hline SJM & Healthy child clinic & 40 & 1.59 & 5.29 & 6.94 \\
\hline \multirow[t]{2}{*}{ P Libre } & Healthy child clinic & 206 & 8.21 & 6.64 & 6.99 \\
\hline & Total & 2,510 & 100 & 9.9 & 5.8 \\
\hline
\end{tabular}

District

\begin{tabular}{llrrrr} 
PLibre & Hospital Santa Rosa & 199 & 22.77 & 2.58 & 1.45 \\
\hline SJM & Hospital María Auxiliadora & 67 & 7.67 & 2.67 & 1.66 \\
\hline Lima & Hospital San Bartolomé & 203 & 23.23 & 3.58 & 2.89 \\
\hline Lima & Ins. Maternal Perinatal & 203 & 23.23 & 3.77 & 2.03 \\
\hline Callao & Hospital D aniel Alcides Carrión & 202 & 23.1 & 4.13 & 2.85 \\
\hline & Total & 874 & 100 & 3.5 & 2.4
\end{tabular}

* Recruitment centers located near mineral deposits SD Standard deviation

parents reported that they had the habit of eating modeling clay displayed more elevated blood lead levels $(2.2 \mu \mathrm{g} / \mathrm{dl})$. Considering both behaviors described above simultaneously and adjusting for age and place

\begin{tabular}{|lr|}
\hline \multicolumn{2}{|c|}{$\begin{array}{c}\text { Descriptive analyses for soil lead } \\
\text { samples }(\mu \mathrm{g} / \mathrm{g})\end{array}$} \\
\hline Sample size & 46 \\
Minimum & 52 \\
Percentil 25 & 98 \\
Mean & 542 \\
Median & 214 \\
Percentil-75 & 623 \\
Maximum & 2859 \\
\hline
\end{tabular}

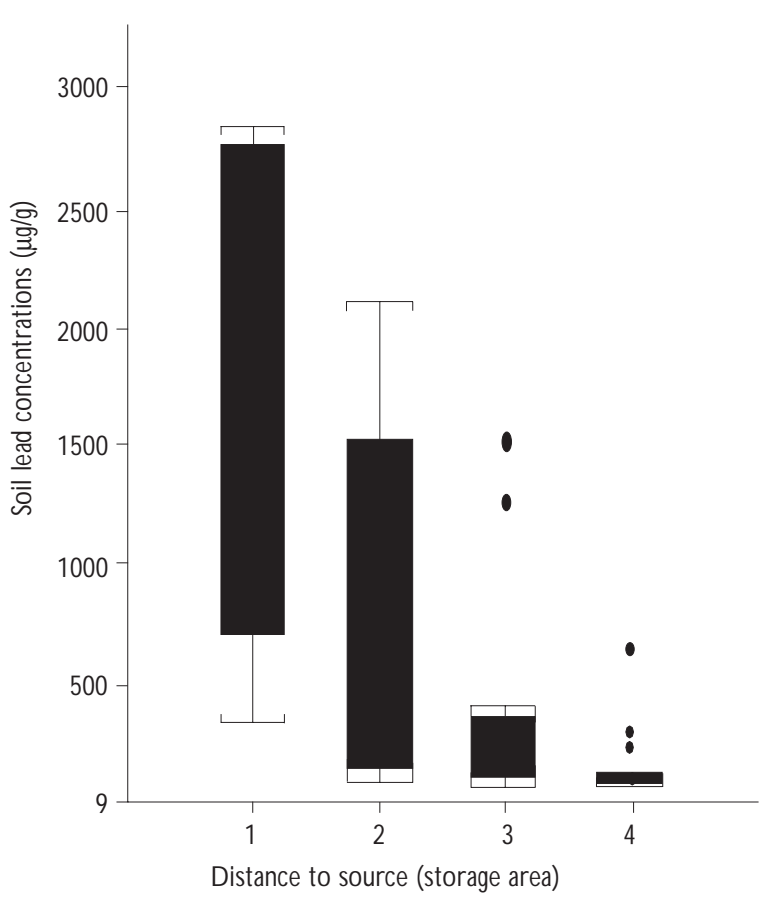

$1=0-300 \mathrm{~m}, 2=301-600 \mathrm{~m}, 3=601-900,4=901-1200 \mathrm{~m}$

Figure 2. Descriptive analyses for soll lead and DISTRIBUTION ACCORDIING TO DISTANCE TO THE STORAGE area. Lima and Callao, Perú, 1998-1999

of residency (Table II), only the habits of eating soil and playing with modeling clay remained as statistically significant predictors; the first was associated with an increase of $1.1 \mu \mathrm{g} / \mathrm{dl}$ and the second with an increase of $1.6 \mu \mathrm{g} / \mathrm{dl}$. The variables associated with the risk of having blood lead levels higher than $10 \mu \mathrm{g} / \mathrm{dl}$, adjusting for age and sex, presented similar results as those previously described. For the total sample studied, eating soil was associated with an increase of $64 \%$ (OR 1.64, 95\% CI: 1.25-2.16) in the risk of showing values higher than $10 \mu \mathrm{g} / \mathrm{dl}$, while biting or sucking pencils was associated with an increased risk of 37\% (OR 1.37, 95\% CI: 1.14-11.65). Children living in Callao displayed an increase of $92 \%$ (OR 1.92, 95\% CI: 1.25-3.06) 
Table II

\section{Differences IN BLOOD LEAD LEVELS ACCORDING TO DIFFERENT BEHAVIORS STUDIED:} Lima Metropolitan Area and Callao, 1998-1999

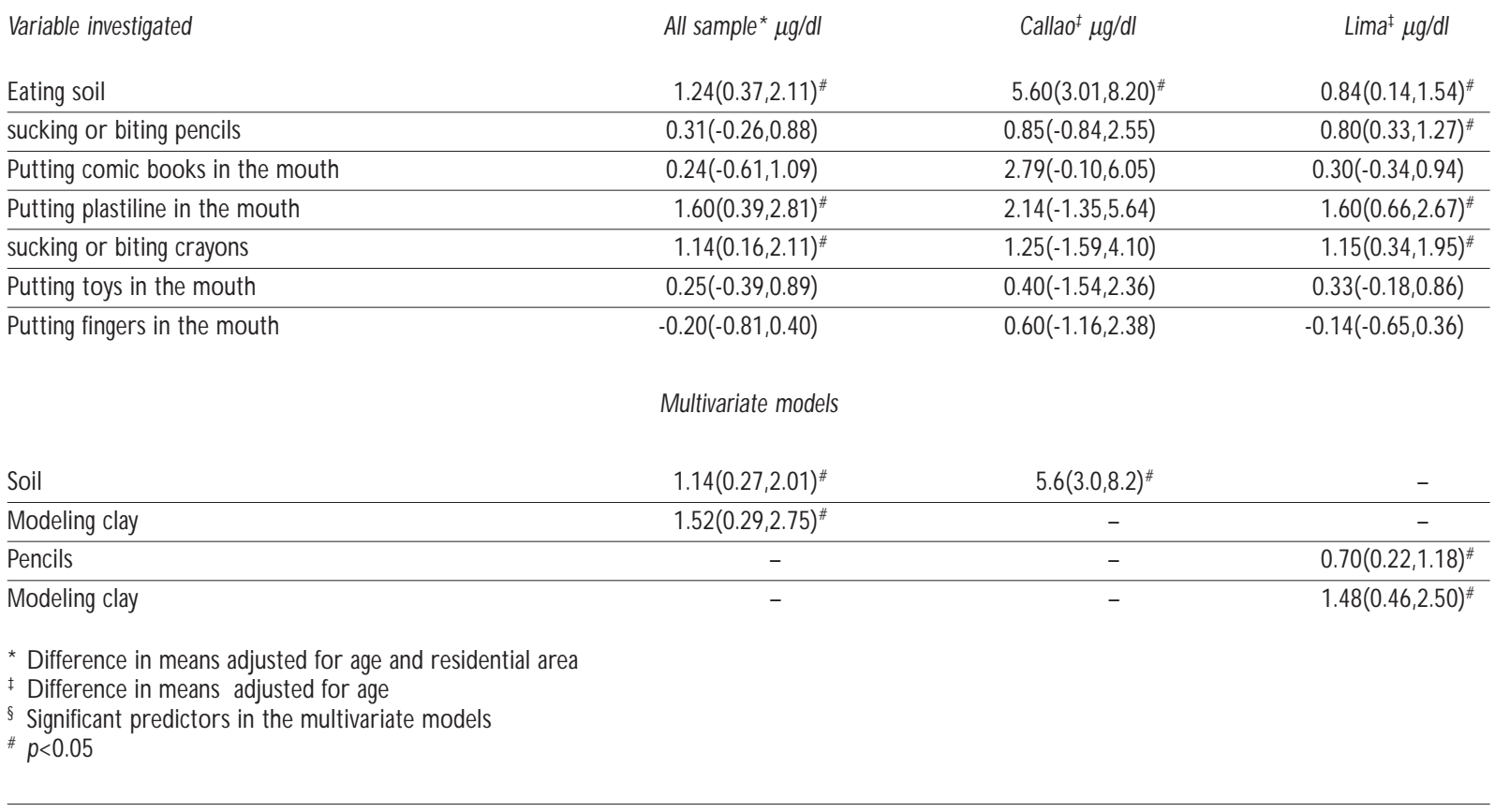

in the risk of having high blood lead levels in relation to the above mentioned variable.

\section{Exposure to vehicular traffic}

The type of transportation used by the participant to go to school, waiting time and location of the home were variables studied in the questionnaire. Walking to school was associated with an increase in blood lead level in comparison with other means of transportation. In the whole population, an excess in the blood lead level of $2.2 \mu \mathrm{g} / \mathrm{dl}$ was associated with walking to school after adjusting for differences in age and sex. An excess of $0.61 \mu \mathrm{g} / \mathrm{dl}$ and $2.0 \mu \mathrm{g} / \mathrm{dl}$ were detected in the children of Lima and Callao, respectively, when analyzing them separately. In the population of Callao the variable of major predictive power was the type of street where the houses were located (Table III). These results, however, are distorted by the fact that a large number of the participants (53\%) who lived near the mineral deposits reported that they lived in narrow dead-end streets with low vehicular traffic. The most important predictors for the residents of Lima were: walking to school and the intensity of vehicular traffic in the residential zones.

\section{Exposure to paints}

The questionnaire results as well as a limited sample of house paint chips did not suggest that paints were an important source of lead exposure in the population studied.

Variables associated with residence and exposure to lead

Eighty-one percent of the population studied reported that they obtained water directly from their homes. They displayed blood lead levels significantly lower than those who obtained water from cylinders, from only one source in the neighborhood or from a source outside the house.

\section{Place of storage of the minerals}

In the questionnaire, the presence of mineral concentrates near the dwelling was studied. Children whose parents reported the presence of these storage sites near their houses had, on average, an excess of $13 \mu \mathrm{g} / \mathrm{dl}$ of blood lead. Living near these sites is associated with an 18-fold increase in the risk of having blood lead levels higher than $10 \mu \mathrm{g} / \mathrm{dl}$ (OR 18.38, CI 95\% 11.18 -30.22). 
Table III

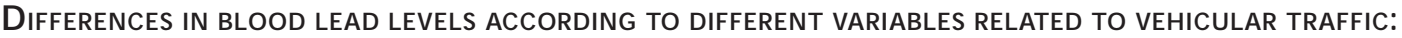 Metropolitan and Callao,1998-1999}

\begin{tabular}{|c|c|c|c|}
\hline & Total sample* $(\mu \mathrm{g} / \mathrm{dl})$ & Callao ${ }^{\ddagger}(\mu \mathrm{g} / \mathrm{dl})$ & $\operatorname{Lima}^{\ddagger}(\mu \mathrm{g} / \mathrm{dl})$ \\
\hline ansport to school & & & \\
\hline By foot vs. other wavs & $2.28(1.24,3.33)$ & $2.09(-1.01,5.20)$ & $0.71(0.17 .1 .25)$ \\
\hline
\end{tabular}

Time awaiting transport in the street

\begin{tabular}{lcrc} 
Less than 10 minutes & Reference & \multicolumn{1}{c}{ Reference } & Reference \\
\hline 10-15 minutes & $-0.04(-1.47,1.39)$ & $0.12(-4.54,4.79)$ & $0.41(-0.51,1.340$ \\
\hline 16-30 minutes & $-1.34(-5.62,2.92)$ & $-10.24(-30.41,9.92)$ & $0.05(-2.48,2.59)$ \\
\hline More than 30 minutes & $-1.87(-4.11,0.36)$ & $-4.19(-11.74,3.34)$ & $-0.56(-2.02,0.88)$
\end{tabular}

The traffic where participant lives is:

\begin{tabular}{lrrr} 
Moderate & $-0.10(-0.82,0.60)$ & $-4.61(-6.80,-2.41)$ & $0.30(-0.26,0.87)$ \\
\hline Heavy & $0.53(-0.10,1.16)$ & $-1.88(-3.74,-0.02)$ & $0.96(0.44,1.48)$
\end{tabular}

Participant's house is situated on:

\begin{tabular}{lccc} 
Avenue & $0.68(0.03,1.33)$ & $4.94(3.01,6.87)$ & $0.11(-0.40,0.63)$ \\
\hline Dead end street & $1.86(1.09,2.63)$ & $11.0(9.17,12.0)$ & $0.07(-0.58,0.73)$ \\
\hline Intersection of principal avenues & $1.94(0.31,3.57)$ & $5.41(0.09,10.7)$ & $0.58(-0.67,1.83)$ \\
\hline Street & Reference & Reference & Reference \\
\hline Highway & $1.60(-2.36,5.57)$ & $3.03(-7.38,13.4)$ & $-0.51(-3.92,2.88)$
\end{tabular}

Multivariate Models

\begin{tabular}{lcc} 
By foot vs. others & $2.44(1.39,3.48)$ & $0.61(0.07,1.15)$ \\
\hline Less than 10 minutes & Reference & Reference \\
\hline $10-15$ minutes & & \\
\hline $16-30$ minutes & & \\
\hline More than 30 minutes & $0.81(0.13,1.49)$ \\
\hline Moderate traffic & $0.97(0.36,1.58)$
\end{tabular}

The house where participant lives is on:

\begin{tabular}{lcc} 
Avenue & $1.10(-0.01,2.23)$ & $4.94(3.01,6.87)$ \\
\hline D ead- end street & $3.36(2.34,4.97)$ & $11.0(9.17,12.0)$ \\
\hline Intersection of principal avenues & $0.65(-2.2,3.52)$ & $5.41(0.09,10.7)$ \\
\hline Street & Reference & Reference \\
\hline Highway & $3.48(-2.83,9.70)$ & $3.03(-7.38,13.4)$
\end{tabular}

* Difference of means adjusted for age and area of residence

₹ Difference of means adjusted for age

$\S$ Significant predictors in the multivariate models

$\# p<0.05$

\section{Exposure in relation to occupation}

The father s occupation was a risk factor for high blood lead levels among the children studied. If the father had an occupation that involved lead exposure and his working clothes were cleaned at home, the child was three times more likely to have a high blood lead level. However, this finding should be interpreted with caution because of the small percentage of children exposed to this risk factor. This type of potential ex- 
posure was reported in less than $1 \%$ of the children sampled.

\section{Multivariate analysis}

The simultaneous effects of the different predictors of blood lead levels were evaluated in multiple regression models. The predictors with statistical significance were sex, age, eating soil, sucking or biting pencils, parent s occupation and place of residence.

The most important predictors identified in the analysis were similar for Callao and Lima. When the stratified analysis was carried out, however, frequent hand washing in Callao and the intensity of vehicular traffic for the Lima population were variables of importance.

\section{Results in women in immediate post- partum period}

The 874 women studied had a mean age of 25.5 years $(\mathrm{SD}=6.2)$. Approximately $80 \%$ were married and only $86 \%$ reported having completed elementary school or a higher level of education. The mean number of children of the participants was $1.9(\mathrm{SD}=1.3)$. Their mean blood lead level was $3.5 \mu \mathrm{g} / \mathrm{dl}$ (range $0.2 \mu \mathrm{g} / \mathrm{dl}$ to 28.2 $\mu \mathrm{g} / \mathrm{dl})$ and $2.4 \%(n=21)$ had blood lead levels higher than $10 \mu \mathrm{g} / \mathrm{dl}$.

Blood lead levels varied by hospital and a statistically significant difference was observed between women recruited in the hospital that provides services to the population living in Callao, with a mean blood lead level of $4.1 \mu \mathrm{g} / \mathrm{dl}$, and women recruited from hospitals providing service to other areas in Lima, where we observed a mean blood lead level of $2.8 \mu \mathrm{g} / \mathrm{dl}$.

Other variables such as length of time living in Lima and smoking during pregnancy were significantly related to blood lead levels. Women who had lived longer in Lima had higher blood lead levels. Other variables used, such as exposure to traffic, time spent outdoors, husbands occupation, and type of transportation were not significantly associated with the women $\mathrm{s}$ blood lead levels. It is important to mention however, that women who indicated the presence of mineral storage areas near their houses $(n=2)$ had blood lead levels nearly two times higher than the rest of the participants; $6.55 \mu \mathrm{g} / \mathrm{dl}$ versus $3.55 \mu \mathrm{g} / \mathrm{dl}$, respectively.

\section{Discussion}

This is the first large cross-sectional study that has been performed to evaluate blood lead levels and their determinants in Lima, and it constitutes a baseline as- sessment of blood lead levels in children to evaluate the potential impact of removing lead from gasoline. In the indexed literature, we located only two publications that reported information regarding blood lead levels in the general population of Lima. Ramírez et al. Reported a mean blood lead level of $26.9 \mu \mathrm{g} / \mathrm{dl}$ in a sample 80 adults with non-occupational exposure. ${ }^{13}$ This value differs from the results of our study, most likely due to selection bias in the Ramírez study, or its use of poor laboratory methods, or an error in its reporting of units for lead measurements. The second study reported a mean blood lead level of $11.7 \mu \mathrm{g} / \mathrm{dl}$ among 40 young children, ${ }_{1}^{14}$ a value which is in agreement with our results. This last study included an external laboratory control provided by the Center for Disease Control and Prevention in Atlanta, Georgia.

The results of our study are important for several reasons. First, they provide valuable information regarding childrens blood lead levels and their determinants in Metropolitan Lima and Callao. Second, they illustrate the application of a new portable and easyto-use technology to assess blood lead levels in the context of a large epidemiological study. This technology is a cost-effective alternative for countries that do not want to invest the funds needed to develop a full atomic absorption based laboratory for blood lead testing. However, the results of this study only represent the risk from lead exposure in six districts of Lima and Callao at one time of the year and should not be extrapolated to other child populations in Peru of different socioeconomic levels and degrees of exposure to gasoline lead or additional point sources. It also marks the first time that internationally accepted methods to evaluate blood lead levels in children have been used in Peru and provides a foundation for further population-based evaluations.

The blood lead levels in the population studied in the Lima metropolitan area were $7.1 \mu \mathrm{g} / \mathrm{dl}$ for children and $3.5 \mu \mathrm{g} / \mathrm{dl}$ for the women in the reproductive age group and demonstrate that blood lead concentrations are not as alarming as previously reported..$^{13}$ The levels of exposure were only slightly elevated and were within the blood lead levels recommended by the World Health Organization which is $10 \mu \mathrm{g} / \mathrm{dl}$. Nonetheless, this should not discourage efforts to control exposure because available data suggest that health effects, such as reduction in IQ are still observed at levels below the $10 \mu \mathrm{g} / \mathrm{dl}$ threshold. ${ }^{15}$

Our results for children living in Lima are similar to those obtained by Romieu et a ${ }^{16}$ in a study done in Mexico City during the time that leaded gasoline was still in use. It reported a mean blood lead level of 9.4 $\mu \mathrm{g} / \mathrm{dl}(\mathrm{SD}=6 \mu \mathrm{g} / \mathrm{dl})$ among children who lived in the 
southern part of Mexico City (Tlalpan, a residential area), and a mean blood lead level of $10.5 \mu \mathrm{g} / \mathrm{dl}$ $(\mathrm{S} . \mathrm{D}=5.5 \mu \mathrm{g} / \mathrm{dl}$ ) among children living in the northern part of Mexico City (Xalostoc, an industrial area). Our results are also similar to those reported for other countries like Nicaragua, $7.4 \mu \mathrm{g} / \mathrm{dl}$, and Uruguay, $9.5 \mu \mathrm{g} /$ $\mathrm{dl}$, both of which were reported by Romieu et al. ${ }^{17}$

Our results also indicate that soils contaminated with lead remain a persistent problem because of the long half-life of lead in soils. Compared with gasolinederived lead, lead derived from other sources proportionally affects a smaller number of residents in the zones studied. Such sources, however, disproportionately affect children of low-income families living in poverty, like those studied in Puerto Nuevo, Callao, where very high lead levels were documented. This is an important factor to bear in mind when designing intervention strategies and employing corrective measures in order to avoid inequitable public health situations. Programs to eliminate gasoline, in other words, are not sufficient to eliminate high blood lead levels in all sectors of the population. Additional work must be done to identify other sources of lead exposure. Efforts should be made to increase lead testing aimed at specific populations and with the purpose of detecting potential problems before children develop the toxic effects of lead. Environmental screening methods available at relatively low cost can now be used to help identify the most immediately hazardous settings in order to speed interventions that will reduce environmental lead exposure.

Scientific reports have demonstrated the existence of different lead sources and that hand mouth activity in children is the main route of ingestion for lead contained in soil, dust, paint, and other mining sources. $9,12,17-22$ There may e two pat ways of exposure for children in the case of mine waste or mine products: one is the movement of mine wastes/products to other areas, which is unlikely given that the storage areas in Callao are well kept from the population by high fences; and the other is contact with areas near homes which may have become contaminated with mine wastes or products. In the case of Callao, this second pathway is the more likely contaminator, given that ore piles are not covered and have not been humidified to prevent fugitive dusts. It is therefore likely that wind-blown dust has contaminated the areas where children play for many years. This may even include the interiors of their houses, because houses in this area are not close and have a high exchange with the external environment. This hypothesis is supported by the observation of high lead concentration in dust samples from residential areas and by data from the air monitoring network. During the study period lead concentrations in PST were $7.3 \mu \mathrm{g} / \mathrm{m}^{3}$, a value well above the recommended value of $1.5 \mu \mathrm{g} / \mathrm{m}^{3}{ }^{3,23}$

Children living close to the mineral storage areas had a mean blood lead level of $25.6 \mu \mathrm{g} / \mathrm{dl}$, while children living in the same district but away from the storage area had a mean blood lead of $9.6 \mu \mathrm{g} / \mathrm{dl}$. This difference $(16 \mu \mathrm{g} / \mathrm{dl})$ is considerably higher than what has been reported for other studies relating blood lead levels to soil lead concentrations in old mining areas contaminated with mine wastes and without any recent smeltering activities. ${ }^{24}$ In a review of these studies Steele et al reported either no differences or slopes of 2.2 for an increase of $500 \mathrm{ppm}$. In our study we observed a difference of $2645 \mathrm{ppm}$ in the soils, which suggests a higher slope. Other factors not analyzed in our study may explain this higher slope, for example the size and solubility of particles, the iron status of these children as well as the hygiene practices. In this population, not washing hands was a strong predictor of blood lead levels. Additional data will be needed to better understand the relationship observed in our study population. Bias due to external contamination is also a possible explanation for the high blood levels documented in this sample. However, all children with blood lead higher than $20 \mu \mathrm{g} / \mathrm{dl}$ were confirmed by blood lead determination in venous blood sample that was measured using atomic absorption. In addition we followed a strict protocol for hand washing and we believe this source of bias does not explain our findings.

When we analyze the case of Callao, we note that there are different sources of lead apart from that of gasoline that contribute to these blood lead levels. The principal source in Callao can be attributed to the presence of mineral storages near the houses or schools where the children lived or studied. The levels of lead in soil increased the closer we got to the mineral deposits, and this was also reflected in the high blood lead levels found in these children. This finding is in accordance with that of other authors who found lead exposures to point sources. ${ }^{12,20,24-28}$ Gallacher et al. (1984) reported that the blood lead level increases 4.5 $\mu \mathrm{g} / \mathrm{dl}$ for each $1000 \mathrm{ppm}$ of lead in soil. In our study we cannot calculate this result because we did not obtain information regarding lead in environmental samples from the individual households. However, Naeher et al..$^{29}$ conducted a study to assess the contributions of different exposure sources to blood lead levels in the same children from our study population using the lead isotope composition of different sources and matching it to the composition observed in the blood. The findings from this study strongly suggested that 
mineral lead was the primary source of lead in the children living near the depository in Callao, and that this differed from the primary source of lead exposure for children in other regions.

In 1998, Peru was the eighth largest producer of lead worldwide and one of the principal users of lead in different industries, including lead in gasoline. In Lima and Callao, according to the National Information of the State of the Environment, it is reported that the motor vehicle fleet was made up of 700000 vehicles, with an average lifespan of 18 years and consumed 9 thousand cubic meters of fuel on a daily basis. There is no information on how much lead was transferred to the environment.

The use of lead in gasoline as anti-knock is present only in some Latin American countries and the Caribbean at present. Romieu et al. reported in $1994^{30}$ that lead concentrations in gasoline ranged from $1.32 \mu \mathrm{g} / \mathrm{dl}$ in Surinam to $0.03 \mu \mathrm{g} / \mathrm{dl}$ in Uruguay. At this moment, in Peru, lead contained in gasoline was $0.75 \mu \mathrm{g} / \mathrm{l}$, with plans to eliminate lead in gasoline by 2005 . This goal is very important as $75 \%$ of the population in Latin America and the Caribbean is urbanized, and therefore the impact of leaded gasoline is of major importance for public health, as reported by Romieu et al. ${ }^{9,12,16,31}$ Finally, our study documents the presence of inequity with regard to environmental exposures because the poorest children are exposed to the greatest amount of lead. The effects of that exposure accumulate among populations already subject to other social deprivations, making the cycle of poverty a more difficult barrier for development.

\section{References}

1. Howson CP, Hernández-A vila M, Rall DP, Ed. Lead in the Americas:A call for action. W ashington, DC:US N ational A cademy of Sciences and the $\mathrm{N}$ ational Institute of Public Health of Mexico, 1996.

2. Rabinowitz M, N eedleman HL. Petrol lead sales and umbilical cord blood lead levels in Boston, Massachusetts [letter].Lancet 1983; 1(8314-5):63.

3. Hernández-Avila M, Sanín LH, Romieu I et al. Higher milk intake during pregnancy is associated with lower maternal and umbilical cord lead levels in postpartum women. Environ Res 1997;74(2):116-121. 4. Rothenberg SJ, Karchmer S, Schnaas L, Perroni E, Zea F, SalinasV et al. Maternal influences on cord blood lead levels. J Exp Asses Environ Epidemiol 1996;6:211-227.

5. Schlenker TL, Fritz C J, Mark D, Layde M, Linke G, Murphy A et al. Screening for pediatric lead poisoning: C omparability of simultaneously drawn capillary and venous blood samples. JAMA 1994;271(17): 1346-1348.
6. Sargent JD, D alton MA. Rethinking the threshold for abnormal capillary blood lead screening test. Arch Pediatr Adolesc Med 1996;150(10):1084-1088.

7. Johnson N H, Ash KO, N uttall KL,A shwood ER. The adecuacy of capillary specimens for determining whole blood lead. Ann Clin Lab Sci 1997;27:179-184.

8. $N$ ational Institute for $O$ ccupational Safety and $H$ ealth. Manual of analytical methods. Fourth Edition. Department of Health, Education and W elfare, 1994.

9. Centers for Disease Control. Preventing lead poisoning in young children: $A$ statement by the $C$ enters for D isease Control.Atlanta (GA): CDC,1991:

10. Ashley K. Ultrasonic extraction and field-portable anodic stripping voltametry of lead from environmental samples. Electroanalysis 1994;7:1189-1192.

11. A merican Society for Testing and Materials. E1775-96 Standard guide for evaluating performance of on-site extraction and field-portable electrochemical or spectrophotometric analysis for lead. In: Ed.Annual Book of ASTM Standards. W est Conshohocken (PA):ASTM, 2000. 12. Rubín CH, Esteban E, Jones R, N oonan G, G urvich E, Utz S et al. Childhood lead poisoning in Russia:A site-specific pediatric blood lead evaluation. Int J 0 ccup Environ Health 1997;3:241-248.

13. Ramírez AV, Paucar JC, Medina JM. Blood lead levels in the inhabitants of 4 Peruvian localities. Pan Am J Public Health. 1997;1(5):344-348.

14. Jacoby E. Environmental lead is a problem in Lima, Peru. Environ Health Perspect 1998;106:A170-171.

15. Schwartz J. Low-level lead exposure and children's IQ :A metaanalysis and search for a threshold. Environ Res 1994;65(S1):42-55. 16. Romieu I, Carreón T, López L, Palazuelos E, Ríos C, Manuel I et al. Environmental urban lead exposure and blood lead levels in children of Mexico City. Environ Health Perspect 1995;103(11):1036:1040.

17. Romieu I et al. Lead exposure in Latin A merica and the $\mathrm{C}$ aribbean. Lead Research Group of the Pan-A merican Health 0 rganization. Environ Health Perspect 1997;105(4):398-405.

18. $\mathrm{N}$ ational A cademy of Sciences. Measuring lead exposure in infants, children, and other sensitive populations. W ashington, DC: $N$ ational A cademy of Sciences Press, 1993.

19. Bjerre B, Berghend M, Harsboo K, Hellman B. Blood lead concentrations of Swedish preschool children in a community with high lead levels from mine waste in soil and dust. Scan JW ork. Environ Health 1993;19:154-161.

20. 0 rdóñez B, Ruiz-Romero L, Mora R. Investigación epidemiológica sobre niveles de plomo en la población infantil y en el medio ambiente domiciliario de Ciudad Juárez, Chihuahua en relación con una fundición de El Paso Texas. Bol 0 ficina Sanit Panam 1976:303-317.

21. Jiménez C, Romieu I, Palazuelos E, Muñoz I, Cortés M, Rivero A et al Factores de exposición ambiental y concentraciones de plomo en sangre en niños de la Ciudad de México. Salud Publica Mex 1993;35:599-606.

22. A gency for Toxic Substances and Disease ATSD R. Registry/C ase studies in environmental medicine: Lead toxicity. Atlanta (GA): 1990. 23. N arciso-C hávez J, G astañaga-Ruiz C, Espinoza-Laín R, SánchezZavaleta C, Moscoso- Reátegui S, Q uequejana-C ondori JL et al. Environmental health project. Act Rep 2000;104:5-25.

24. Steele MJ, Beck BD, Murphy BL, Strauss H. Assessing the contribution from lead in mining wastes to blood lead. RegToxic Pharm 1990;11:158-190.

25. Gulson BL, Mizon KJ, Law AJ, Korsch MJ, D asis JJ. Sources and pathways of lead in humans from the Broken Hill mining community An alternative use of exploration methods. Econ G eol 1994;89:889-908. 26. Gulson BL, Mizon KJ, Korsch MJ, Howarth D. N on-orebody sources are significant contributors to blood lead of some children with low to 
moderate exposure in a major lead mining community. Sci Total Environ 1996;181:223-230.

27. Bornschein RL, Clark CS, G rote J, Peace B, Rodaa S, Succop P. Soil lead-blood lead relationships in a former lead mining town. Environ Geochem Health 1989;:140-160.

28. Gallacher JE, Elwood PC, Phillips KM, D avies BE, Jones DT. Relation between pica and blood lead in areas of differing lead exposure.Arch Dis Child 1984;59:40-44.

29. N aeher LP, Rubín CS, Hernández-A vila M, N o onan G P, Paschal D, $\mathrm{N}$ arciso J et al. Use of isotope ratios to identify lead sources contributing to pediatric lead posisonnings in Callao, Peru. Arch Environ Health. In press.

30. Romieu I, Palazuelos E, Hernández-Avila M, Ríos C, Muñoz I, Jiménez $C$ et al. Sources of lead in México City. Environ Health Perspect 1994;102:384-389.

31. H ayes EB, MC Elvaine MD, 0 rbach HG, Fernández AM, Lyne S, Matte

TD. Long-term trends in blood lead levels among children in Chicago:

Relationship to air lead levels. Pediatrics 1994:93(2):195-200. 